\title{
ВИЗНАЧЕННЯ ТЕМПЕРАТУРИ В КРУГЛІЙ ПЛАСТИНІ 3 БАГАТОШАРОВИМИ ПОКРИТТЯМИ
}

\author{
Віктор Семерак, к. т. н., Йосип Лучко, д. т. н., Олександр Пономаренко, к. ф.-м. н., \\ Володимир Косарчин, к. ф.-м. н. \\ Львівський національний аграрний університет, \\ вул. Володимира Великого, 1, м. Дубляни, Львівський р-н, Львівська обл., Украӥна, \\ e-mail:semerakviktor@gmail.com
}

https://doi.org/10.31734/agroengineering2021.25.120

\begin{abstract}
Семерак В., Лучко Й., Пономаренко О., Косарчин В. Визначення температури в круглій пластині з багатошаровими покриттями

Довгострокова безвідмовна робота газових турбін значною мірою залежить від здатності матеріалів працювати за високих температур і дії агресивного попелу і продуктів згоряння. Значення цієї температури залежно від типу турбіни є в межах 960-1300 ${ }^{\circ} \mathrm{C}$, а в деяких видів турбін буває навіть вище. 3 цією метою розробляються нові сплави, композиційні та інші матеріали, а також технології підвищення жаростійкості і жароміцності деталей газових турбін за допомогою формування поверхневих шарів з відповідними фізико-механічними властивостями. Однак найефективнішим і найбільш широковживаним способом забезпечення жароміцності та корозійної стійкості конструкційних елементів гарячого тракту газотурбінних двигунів є нанесення поверхневих покриттів.

Побудовано математичну модель для оболонки довільної форми з одностороннім та двостороннім багатошаровими тонкими покриттями, поверхні якої контактують із зовнішніми середовищами різних температур. За допомогою операторного методу розв'язок тривимірної задачі теплопровідності оболонки з покриттям зведено до системи двох диференціальних рівнянь для інтегральних характеристик температури. Одержано в замкнутому вигляді точні розв'язки стаціонарних та нестаціонарних задач теплопровідності для круглої пластини та диска 3 двосторонніми тонкими багатошаровими покриттями.

Розрахунки проводилися для суцільної круглої пластини. 3 представлених результатів розрахунків температури плити видно, що ігнорування покриттів завищує розрахункову температуру приблизно на $100{ }^{\circ} \mathrm{C} .3$ розподілу напружень ми спостерігаємо протилежну картину. Врахування покриттів дає зниження значення напружень приблизно на 70 МПа до центру пластини, а також до центру і до краю пластини.
\end{abstract}

Ключові слова: температура, теплопровідність, оболонка 3 багатошаровими покриттями, кругла плита, антикорозійне двостороннє двошарове покриття.

\section{Semerak V., Luchko Y., Ponomarenko A., Kosarchyn V. Measuring temperature in a round plate with multilayer coatings}

A long-term trouble-free operation of gas turbines significantly depends on the material's ability to operate at high temperatures and the effects of aggressive pressure and combustion products. The value of this temperature, depending on the type of turbine is within the range of $960-1300{ }^{\circ} \mathrm{C}$, whereas in other types of turbines, it is higher. Using the basis, new alloys, composite and other materials are developed, as well as the technology to increase the stability and heat resistance of gas turbine parts during formation of surface layers with appropriate physical and mechanical properties.

However, the most effective and broadest way to ensure the safety and corrosion resistance of structural elements of the general path of gas turbine engines is to apply surface coatings.

A mathematical model for a shell of arbitrary shape with one-sided and two-sided multilayer thin coatings, the surfaces of which are in contact with external environments of different temperatures, is constructed. Using the operator method, solutions of the three-dimensional problem of thermal conductivity of the coated shell are reduced to a system of two differential equations for the integral characteristics of the temperature. The exact solutions of stationary and nonstationary thermal conductivity problems for a round plate and a disk with bilateral thin multilayer coatings are obtained in a closed form.

The calculations were performed for a solid round plate. From the presented results of calculations of the temperature of a plate, it is observed that neglecting coverings results in overestimates of the design temperature approximately by $100{ }^{\circ} \mathrm{C}$. From distribution of stresses, an opposite picture is marked. Consideration of coatings provides for reduction of the values of stressed by about $70 \mathrm{MPa}$ to the center of the plate, as well as to the center and to the edge of the plate.

Key words: temperature, thermal conductivity, shell with multilayer coatings, round plate, anti-corrosion double-sided double-ply coating.

Постановка проблеми. Довготривала безаварійна експлуатація газових турбін істотно залежить від здатності матеріалу до роботи за високих температур і впливу на них агресивного попелу й продуктів згоряння. Значення цієї температури залежно від типу турбіни $€$ в 
діапазоні 960-1300 ${ }^{\circ} \mathrm{C}$, а в деяких видах турбін буває навіть вище. 3 цією метою проводяться розробки нових сплавів, композитних та інших матеріалів, а також технологій підвищення жаростійкості і жароміцності деталей газових турбін за допомогою формування поверхневих шарів із відповідними фізичними та механічними властивостями.

Однак найефективнішим і найбільш широковживаним способом забезпечення жароміцності і корозійної стійкості конструкційних елементів гарячого тракту газотурбінних двигунів $\epsilon$ нанесення поверхневих покриттів. Нині до $70 \%$ деталей газотурбінних двигунів піддають нанесенню різноманітних покриттів, а кількість деталей, що покриваються, досягає декількох тисяч на мотокомплект [4].

Оболонка, яка поєднує високу міцність i малу вагу, простоту i технологічність виготовлення, стала однією з найпоширеніших конструкцій у різних галузях сучасної техніки, насамперед це корпусні елементи в ракетній i авіаційній техніці, судно- і автомобілебудуванні, промисловому і цивільному будівництві, хімічному машинобудуванні.

Отже, для оболонки довільної форми 3 одностороннім і двостороннім багатошаровими тонкими покриттями, поверхні якої омиваються зовнішніми середовищами з різними температурами, побудована математична модель, за якої вплив багатошарових покриттів на розподіл температури в пластині зводиться до узагальнених умов теплообміну зі зовнішніми середовищами на поверхні оболонки. Матеріали оболонки і покриттів мають різні теплофізичні характеристики. На контактних поверхнях пластини i шарів та між шарами виконуються умови ідеального теплового контакту. За допомогою операторного методу розв'язок рівняння теплопровідності для оболонки записано через інтегральні характеристики температури, які визначаються зі системи двох диференціальних рівнянь.

На основі розробленого підходу розв'язано ряд температурних задач для круглих пластин (днища, покришки тощо) 3 покриттями, які найбільш широко застосовуються в промисловості.

Аналіз останніх досліджень і публікацій. У роботах [5-7] опрацьовано фізико-математичні моделі тіла з урахуванням властивостей проміжних i приповерхневих шарів, тим самим було закладено фундамент нового напряму науки механіки поверхневих явищ і покриттів. Модель грунтується на ідеї про недосконалий тепловий контакт різних середовищ, приповерхневий шар моделюється фізичною поверхнею, яка має всі характеристики шару - провідність, проникність, здатність виділяти (поглинати) тепло, жорсткість тощо. Піонерським дослідженням термопружності у квазістатичній постановці можна вважати роботу [11], в якій вперше представлені рівняння для визначення термопружного стану тіла.

Надалі теорія теплопровідності і термопружності отримала свій розвиток у працях Г. Карслоу і Д. Егера [1], А. В. Ликова [2], Я. С. Підстригача і Ю. М. Коляно [6] та ін. Лінійно пов'язані задачі термопружності досліджені і досить повно висвітлені в огляді [7]. Однією ж із перших робіт щодо пов'язаної термопружності тонкостінних елементів конструкцій $€$ робота [12], де сформульовані пов'язані лінійні задачі термопружності тонких пластин.

3 огляду на труднощі, які виникають при отриманні аналітичних розв'язків задач термопружності для тіл зі складною геометрією, i стрімкий розвиток обчислювальної техніки, для вирішення завдань термомеханіки твердого тіла, що деформується, стали широко застосовувати числові методи, засновані на варіаційних принципах.

Нестаціонарні крайові задачі теплопровідності в точній постановці для покриттів довільної товщини розв'язувалися аналітично [3; $10 ; 13-15$ та ін.]. Так, у працях [10; 13] розроблено аналітичний метод розв'язку задачі теплопровідності для необмеженого твердого ізотропного тіла 3 циліндричним каналом, всередині якого нанесено багатошарове покриття і який заповнений високотемпературним газом, при нестаціонарних режимах теплообміну. В його основу покладена ідея розщеплення ядра узагальненого інтегрального перетворення Вебера. У роботі [3] досліджено тепловий режим циліндричної і сферичної оболонок із захисним покриттям під дією зовнішніх постійних температурних полів. Розглянуто випадки умов ідеального теплового контакту основного i захисного шарів i 3 урахуванням ефекту термічного опору поверхні контакту.

Узагальнену нелінійну граничну умову радіаційно-конвективної взаємодії тіла 3 робочим середовищем через багатошарове тонке покриття отримано з використанням операторного методу в праці [9]. Під час досліджень теплопровідності тіл 3 покриттями практично без уваги залишилися такі явища, як оболонки 3 багатошаровими покриттями. Як бачимо, існують рішення тільки в окремих випадках. Однак немає загальної теорії, яка б дала змогу отримати аналітичний розв'язок 
для визначення температурного поля в довільній оболонці з багатошаровим покриттям при нерівномірному їі нагріванні.

Завдання істотно ускладнюється за наявності тонких шарів покриття, що призводить до труднощів математичного моделювання, які пов'язані, передусім, з урахуванням геометричних i теплофізичних властивостей кожного шару покриття. Як видно з аналізу літератури, теоретичні дослідження теплопровідності в оболонках iз тонкими багатошаровими покриттями практично відсутні. Експериментальні ж дані свідчать про те, що мінливість теплоємності і теплопровідності тонких приповерхневих шарів або покриттів враховувати необхідно.

Особливо цінними є аналітичні розв'язки таких задач, які побудовані у вигляді явних формул, що містять елементарні або спеціальні функції. Такі розв'язки є зручними для аналізу теплових режимів, оскільки явно відображають вплив на розподіл температури визначальних чинників, що дозволяють оцінити їх значення i виділити головні з них. Вони також можуть слугувати критерієм оцінки достовірності числових розв'язків.

Постановка завдання. Наше завдання отримати аналітичні розв'язки таких задач, які побудовані у вигляді явних формул, що містять елементарні або спеціальні функції. Такі розв'язки $\epsilon$ зручними для аналізу теплових режимів, оскільки явно відображають вплив на розподіл температури визначальних чинників, що дозволяють оцінити їх значення і виділити головні з них. Вони також можуть слугувати критерієм оцінки достовірності числових розв'язків.

Виклад основного матеріалу. Математична модель процесу теплопровідності оболонок з двосторонніми багатошаровими покриттями. 3 використанням цього підходу побудована математична модель і для оболонки 3 двосторонніми багатошаровими тонкими покриттями.

На рис. 1 наведено розрахункову схему оболонки 3 двостороннім багатошаровим покриттям.

На поверхні $\gamma_{0}=h_{0}$ оболонки нанесено покриття товщинами $2 h_{1}^{+}, 2 h_{2}^{+}, \ldots, 2 h_{n}^{+}$, а на поверхню $\gamma_{0}=-h_{0}$ оболонки нанесено багатошарове покриття з товщиною $2 h_{1}^{-}, 2 h_{2}^{-}, \ldots, 2 h_{m}^{-}$iз різними теплофізичними характеристиками.

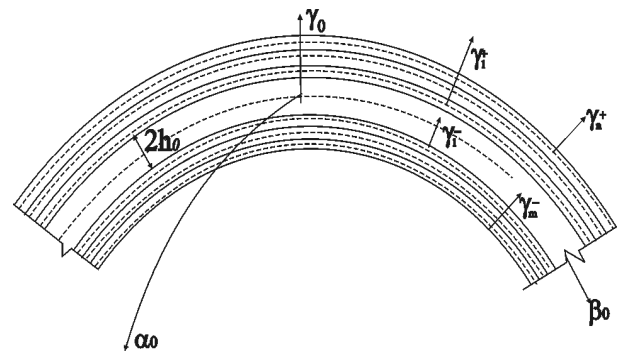

Рис. 1. Оболонка 3 двостороннім багатошаровим покриттям

Fig. 1. The case with a bilateral multilayered covering

Наближена система для визначення інтегральних характеристик температури оболонки 3 двосторонніми багатошаровими покриттями, яку оточують середовища 3 температурами $t_{m}^{c} \mathrm{i} t_{n}^{c}$, отримана у вигляді:

$$
\begin{gathered}
p_{0}^{2} h_{0}^{2} \cdot T_{1}-\varepsilon_{0} T_{1}-\varepsilon_{0}^{*} T_{2}=-\left(\varepsilon_{0} t_{c}+\varepsilon_{0}^{*} t_{c}^{*}\right), \\
p_{0}^{2} h_{0}^{2} \cdot T_{2}-3\left(1+\varepsilon_{0}\right) \cdot T_{2}-3 \varepsilon_{0}^{*} T_{1}=-3\left(\varepsilon_{0} t_{c}^{*}+\varepsilon_{0}^{*} t_{c}\right)
\end{gathered}
$$

3 крайовими умовами:

$$
\begin{gathered}
\frac{\partial \mathrm{T}_{1}}{\partial \gamma}-\frac{\alpha_{0}}{\lambda_{0}}\left(T_{1}-T_{0}^{c}\right)=0, \frac{\partial \mathrm{T}_{2}}{\partial \gamma}-\frac{\alpha_{0}}{\lambda_{0}}\left(T_{2}-T_{0}^{c *}\right)=0 ; \\
\frac{\partial \mathrm{T}_{1}}{\partial \gamma}-\frac{\alpha_{0 n}}{\lambda_{0 n}}\left(T_{1}-T_{n}^{c}\right)=0 ; \\
\frac{\partial \mathrm{T}_{2}}{\partial \gamma}-\frac{\alpha_{0 n}}{\lambda_{0 n}}\left(T_{2}-T_{\mathrm{n}}^{c *}\right)=0 ; T_{1}=T_{0}, \quad T_{2}=T_{0}^{*} \\
\text { при } \tau=0,
\end{gathered}
$$

де

$$
\begin{gathered}
\varepsilon_{0}=\frac{h_{0}}{2}\left(\frac{\alpha_{0 \mathrm{~m}}}{\lambda_{0 m}}+\frac{\alpha_{0 n}}{\lambda_{0 n}}\right) ; \\
\varepsilon_{0}^{*}=\frac{h_{0}}{2}\left(\frac{\alpha_{0 m}}{\lambda_{0 m}}-\frac{\alpha_{0 n}}{\lambda_{0 n}}\right) \lambda_{0 n}=\lambda_{0}\left(1+\alpha_{n} \sum_{i=1}^{n} r_{i}\right) ; \\
\alpha_{0 n}=\alpha_{n}-\sum_{i=1}^{n} \lambda_{i}^{*} ; \\
\lambda_{0 m}=\lambda_{0}\left(1+\alpha_{\mathrm{m}} \sum_{j=1}^{m} r_{j}\right) ; \quad \alpha_{0 m}=\alpha_{m}-\sum_{j=1}^{m} \lambda_{j}^{*} ; \\
t_{c}=\frac{1}{2}\left(t_{m}^{c}+t_{n}^{c}\right) ; t_{c}^{*}=\frac{1}{2}\left(t_{m}^{c}-t_{n}^{c}\right) .
\end{gathered}
$$

Отже, для оболонки довільної форми 3 одностороннім i двостороннім багатошаровими тонкими покриттями, поверхні якої омиваються зовнішніми середовищами 3 різними температурами, побудована математична модель, за якої вплив багатошарових покриттів на розподіл температури в пластині зводиться до узагальнених умов теплообміну із зовнішніми середовищами на 
поверхні оболонки. Матеріали оболонки і покриттів мають різні теплофізичні характеристики. На контактних поверхнях пластини i шарів і між шарами виконуються умови ідеального теплового контакту. За допомогою операторного методу розв'язок рівняння теплопровідності для оболонки записано через інтегральні характеристики температури, які визначаються зі системи двох диференціальних рівнянь.

На основі розробленого підходу розв'язано ряд температурних задач для круглих пластин (днища, покришки тощо) і циліндричних оболонок (резервуари, трубопроводи) 3 покриттями, які найбільш широко застосовуються в промисловості.

Практичне визначення розподілу температури в оболонкових елементах конструкцій 3 тонким багатошаровим покриттям. Пластини i циліндричні оболонки $\epsilon$ основним стримуючим елементом конструкцій у багатьох галузях сучасної промисловості. Це автомобіле- i суднобудування, газова і хімічна промисловість, промислове і цивільне будівництво тощо.

Розглянемо стаціонарне температурне поле в круглій пластині постійної товщини 3 центральним вирізом і двостороннім багатошаровим покриттям. Визначимо стаціонарне плоске температурне поле диска постійної товщини 3 двостороннім багатошаровим покриттям (рис. 2).

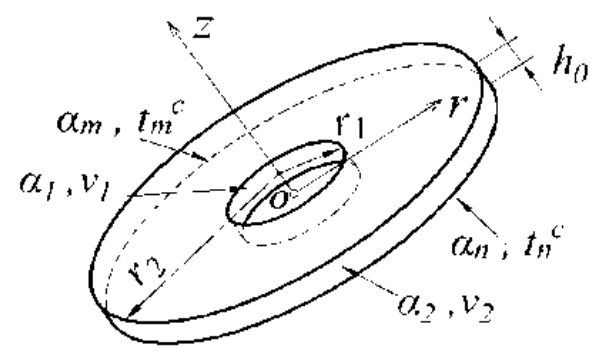

Рис. 2. Диск постійної товщини $з$ двостороннім багатошаровим покриттям

Fig. 2. Disk of constant thickness with a bilateral multilayer covering

Позначимо радіус зовнішнього контуру диска через $r_{2}$, а радіус його внутрішнього контуру - через $r_{1}$. Вважаємо, що між поверхнями диска $z=h_{n}$ i $z=-h_{m}$ відбувається конвективний теплообмін із зовнішніми середовищами при однакових коефіцієнтах теплообміну $\alpha=\alpha_{m}=\alpha_{n}$. Температура середовища при $z=h_{n}$ дорівнює $t_{n}^{c}$, а при $z=-h_{m}-t_{m}^{c}$. Приймаємо, що температура по товщині пластини змінюється за лінійним законом:

$$
t=T_{1}+z T_{2} .
$$

Для вирішення цього завдання використовуємо систему рівнянь (3) за крайових умов (4). У цьому разі, ввівши безрозмірну змінну $\rho=\frac{r}{r_{2}}$ i враховуючи, що $\varepsilon_{0}^{*}=0$, вона набуде такого вигляду:

$$
\begin{aligned}
& \frac{d^{2} T_{1}}{d \rho^{2}}+\frac{1}{\rho} \frac{d T_{1}}{d \rho}-\varepsilon_{0}\left(T_{1}-t_{c}\right)=0, \\
& \frac{d^{2} T_{2}}{d \rho^{2}}+\frac{1}{\rho} \frac{d T_{2}}{d \rho}-\varepsilon_{1}\left(T_{2}-t_{c}^{*}\right)=0
\end{aligned}
$$

за крайових умов:

$$
\begin{aligned}
& \frac{d T_{1}}{d \rho}-\frac{\alpha_{1} r_{2}}{\lambda}\left(T_{1}-v_{1}\right)=0 \text { при } \rho=\rho_{1}, \\
& \frac{d T_{1}}{d \rho}+\frac{\alpha_{2} r_{2}}{\lambda}\left(T_{1}-v_{2}\right)=0 \text { при } \rho=1, \\
& \frac{d T_{2}}{d \rho}-\frac{\alpha_{1} r_{2}}{\lambda} T_{2}=0 \text { при } \rho=\rho_{1}, \\
& \frac{d T_{2}}{d \rho}+\frac{\alpha_{2} r_{2}}{\lambda} T_{2}=0 \text { при } \rho=1,
\end{aligned}
$$

де $\varepsilon_{1}=3\left(1+\varepsilon_{0}\right) ; \quad v_{1} \mathrm{i} \quad \alpha_{1}-$ температура середовища $\mathrm{i}$ коефіцієнт теплообміну на внутрішньому контурі диска $\left(r=r_{1}\right.$ або $\left.\rho=\rho_{1}\right), v_{2}$ i $\alpha_{2}\left(r=r_{1}\right.$ або $\left.\rho=\rho_{1}\right)-$ відповідно на зовнішньому контурі диска $\left(r=r_{2}\right.$ або $\left.\rho=1\right)$.

Розв'язком цієї системи використовуємо результати, наведені у [2]:

$$
\begin{gathered}
T_{1}=t_{c}+C_{1} I_{0}\left(\sqrt{\varepsilon_{0}} \rho\right)+C_{2} K_{0}\left(\sqrt{\varepsilon_{0}} \rho\right), \\
T_{2}=t_{c}^{*}+C_{1}^{\prime} I_{0}\left(\sqrt{\varepsilon_{1}} \rho\right)+C_{2}^{\prime} K_{0}\left(\sqrt{\varepsilon_{1}} \rho\right),
\end{gathered}
$$

де $I_{0}(x)$ і $K_{0}(x)$ - модифіковані функції Бесселя нульового порядку першого і другого роду [10; 11$]$.

Тоді для температурного поля диска отримуємо такий розв'язок:

$$
\begin{gathered}
t=t_{c}+C_{1} I_{0}\left(\sqrt{\varepsilon_{0}} \rho\right)+C_{2} K_{0}\left(\sqrt{\varepsilon_{0}} \rho\right)+ \\
+z\left[t_{c}^{*}+C_{1}^{\prime} I_{0}\left(\sqrt{\varepsilon_{1}} \rho\right)+C_{2}^{\prime} K_{0}\left(\sqrt{\varepsilon_{1}} \rho\right)\right] .
\end{gathered}
$$

Сталі інтегрування шукаємо 3 граничних умов (4), з огляду на відомі формули [10;11]:

$$
\frac{d}{d x} I_{0}(x)=I_{1}(x) ; \quad \frac{d}{d x} K_{0}(x)=-K_{1}(x),
$$

де $I_{1}(x), K_{1}(x)$ - модифіковані функції Бесселя першого порядку відповідно першого і другого роду.

$$
\begin{aligned}
& \text { Знаходимо: } \\
& C_{1}=\frac{1}{\Delta}\left[\gamma_{1}\left(v_{1}-t_{c}\right) v_{1}(\delta)+\gamma_{2}\left(v_{2}-t_{c}\right) v_{2}\left(\delta \rho_{1}\right)\right],
\end{aligned}
$$




$$
\begin{gathered}
C_{2}=\frac{1}{\Delta}\left[\gamma_{1}\left(v_{1}-t_{c}\right) u_{1}(\delta)+\gamma_{2}\left(v_{2}-t_{c}\right) u_{2}\left(\delta \rho_{1}\right)\right], \\
C_{1}^{\prime}=-\frac{t_{c}^{*}}{\Delta_{1}}\left[\gamma_{1} v_{1}\left(\delta_{1}\right)+\gamma_{2} v_{2}\left(\delta_{1} \rho_{1}\right)\right] \\
C_{2}^{\prime}=-\frac{t_{c}^{*}}{\Delta_{1}}\left[\gamma_{1} u_{1}\left(\delta_{1}\right)+\gamma_{2} u_{2}\left(\delta_{1} \rho_{1}\right)\right] \\
u_{2}\left(\delta \rho_{1}\right)=I_{1}\left(\delta \rho_{1}\right)-\frac{\gamma_{1}}{\delta} I_{0}\left(\delta \rho_{1}\right) ; \\
v_{1}(\delta)=K_{1}(\delta)-\frac{\gamma_{2}}{\delta} K_{0}(\delta) ; \\
v_{2}\left(\delta \rho_{1}\right)=K_{1}\left(\delta \rho_{1}\right)+\frac{\gamma_{1}}{\delta} K_{0}\left(\delta \rho_{1}\right) ; \\
\Delta=u_{2}\left(\delta \rho_{1}\right)\left[\gamma_{2} K_{0}(\delta)-\delta K_{1}(\delta)\right]+ \\
+v_{2}\left(\delta \rho_{1}\right)\left[\gamma_{2} I_{0}(\delta)+\delta I_{1}(\delta)\right] ; \\
\delta^{2}=\varepsilon_{0} r_{1}^{2} / h_{0}^{2} ; \delta_{1}^{2}=\varepsilon_{1} r_{1}^{2} / h_{0}^{2} ; \\
\varepsilon_{1}=3\left(1+\varepsilon_{0}\right) ; \gamma_{1}=\frac{\alpha_{1} r_{2}}{\lambda} ; \gamma_{2}=\frac{\alpha_{2} r_{2}}{\lambda} ;
\end{gathered}
$$

величини $u_{1}\left(\delta_{1}\right), u_{2}\left(\delta_{1} \rho_{1}\right), v_{1}\left(\delta_{1}\right), \quad v_{2}\left(\delta_{1} \rho_{1}\right), \Delta_{1}$ визначаються виразами (9) після заміни в них $\delta$ на $\delta_{1}$.

Розглянемо стаціонарне температурне поле в круглій суцільній пластині постійної товщини 3 двостороннім багатошаровим покриттям.

Тут наведено вирішення завдання про стаціонарне температурне поле суцільного диска постійної товщини 3 двостороннім багатошаровим покриттям.

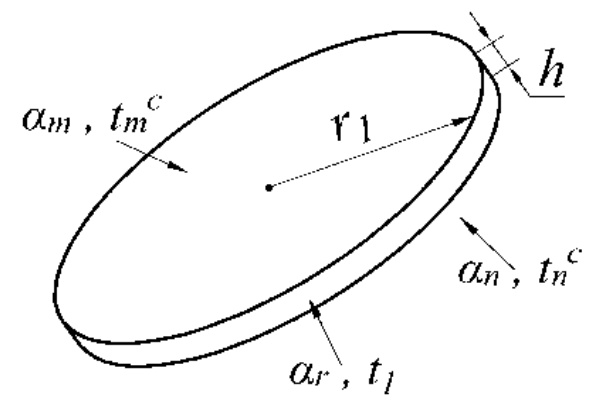

Рис. 3. Кругла суцільна пластина постійної товщини 3 двостороннім багатошаровим покриттям

Fig. 3. Round solid plate of constant thickness with a double-sided multilayer coating

Між зовнішнім контуром пластини $r=r_{1}$, iii поверхнями $z=-h_{m}$ (рис. 3) і навколишнім середовищем відбувається стаціонарний конвективний теплообмін при однакових коефіцієнтах теплообміну $\alpha=\alpha_{m}=\alpha_{n}$.
За таких умов температурне поле змінюється як уздовж радіуса, так і за товщиною пластини. вигляді:

Розв'язок рівняння теплопровідності у

$$
t=t_{c}+C_{1} I_{0}(\delta \rho)+z\left[t_{c}^{*}+C_{2} I_{0}\left(\delta_{1} \rho\right)\right],
$$

де $I_{0}(x)$ - модифіковані функції Бесселя нульового порядку першого роду;

$$
\begin{gathered}
C_{1}=\frac{\chi\left(t_{1}-t_{c}\right)}{\delta I_{1}(\delta)+\chi I_{0}(\delta)} ; \quad C_{2}=\frac{-\chi t_{c}^{*}}{\delta_{1} I_{1}\left(\delta_{1}\right)+\chi I_{0}\left(\delta_{1}\right)} ; \\
\chi=\alpha_{r} r_{1} / \lambda ; \quad \delta^{2}=\varepsilon_{0} r_{1}^{2} / h_{0}^{2} ; \delta_{1}^{2}=\varepsilon_{1} r_{1}^{2} / h_{0}^{2} ; \\
\varepsilon_{1}=3\left(1+\varepsilon_{0}\right) ;
\end{gathered}
$$

$t_{1}$ і $\alpha_{r}$ - температура і коефіцієнт теплообміну на зовнішньому контурі диска $\left(r=r_{1}\right.$ або $\left.\rho=1\right)$.

Нестаціонарне температурне поле в круглій суцільній пластині постійної товщини 3 двостороннім багатошаровим покриттям. Вважаємо, що на поверхнях диска $z=h_{n}$ i $z=-h_{m}$ відбувається однаковий конвективний теплообмін iз зовнішнім середовищем. Тоді температура по товщині пластини буде постійною. Ввівши змінну $\rho=\frac{r}{r_{1}} \quad$ і безрозмірний час $\tau=\frac{t a}{r_{1}^{2}}$, отримуємо для сформульованої задачі рівняння:

$$
\frac{d^{2} T_{1}}{d \rho^{2}}+\frac{1}{\rho} \frac{d T_{1}}{d \rho}-\delta^{2}\left(T_{1}-t_{c}\right)=\frac{\partial T_{1}}{\partial \tau}
$$

за умов:

$$
T_{1}=T_{0} \quad \text { при } \quad t=0,
$$

де $v_{2}$ i $\alpha_{r}$ - температура середовища і коефіцієнт теплообміну відповідно на зовнішньому контурі диска $\left(r=r_{1}\right.$ або $\left.\rho=1\right)$.

Для розв'язання рівняння теплопровідності використовують інтегральне перетворення Лапласа. Після здійснення необхідних перетворень отримаємо такий вираз для температури суцільної пластини:

$$
\begin{aligned}
& T_{1}=t_{c}+\frac{\chi\left(v_{2}-t_{c}\right) I_{0}(\delta \rho)}{\delta I_{1}(\delta)+\chi I_{0}(\delta)}-\sum_{n=1}^{\infty} A_{n} B_{n} J_{0}\left(\beta_{n} \rho\right) e^{-\left(\delta^{2}+\beta_{n}^{2}\right) \tau}, \\
& \text { де } A_{n}=\frac{2 \chi}{\left(\chi^{2}+\beta_{n}^{2}\right) J_{0}\left(\beta_{n}\right)}, B_{n}=\frac{\beta_{n}^{2} v_{2}+\delta^{2} t_{c}}{\left(\delta^{2}+\beta_{n}^{2}\right)}-T_{0} .
\end{aligned}
$$

Приклади розрахунку температури. Вилив протикорозійного двостороннього двошарового покриття на термопружність суцільного диска газової турбіни. Зовнішній шар покриття є керамікою звичайного складу $\mathrm{ZrO}_{2}+$ $8 \% \mathrm{Y}_{2} \mathrm{O}_{3}$. Внутрішні шари покриття $є$ металеві: вони забезпечують адгезію керамічного шару $\mathrm{i}$ додатковий захист від високотемпературної корозії в разі проникнення агресивного середовища через керамічний шар або його розшарування [5]. 
Відмінність коефіцієнтів лінійного розширення в діапазоні температур $20 \ldots 900{ }^{\circ} \mathrm{C}$ в зовнішніх $\left(\alpha=15 \ldots 17 \cdot 10^{-6}\right) \quad$ і внутрішніх $\left(\alpha=9 . .9,5 \cdot 10^{-6}\right)$ шарах створює складну картину напруженого стану при зміні температури. Тому для оцінки працездатності таких конструкційних елементів 3 багатошаровими покриттями важливим $є$ дослідження зміни іх температурного поля і напружено-деформованого стану [8].

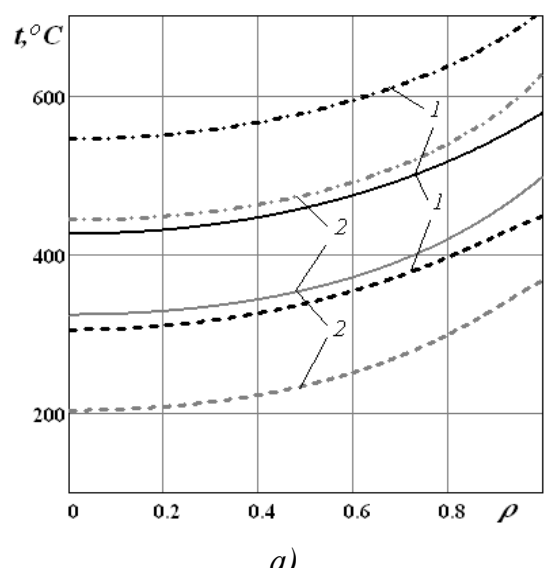

Розрахунки здійснено для суцільної круглої пластини товщиною $h_{0}=0,1 \mathrm{~m}$ i радіуса $r_{1}=0,5 \mathrm{~m}$, яка виготовлена з жароміцного сплаву ЕI 893. На поверхні пластини нанесено двошарове антикорозійне покриття КДП-1 / СДП-8 [8], де КДП-1 (діоксид цирконію, стабілізований $8 \% \mathrm{Y}_{2} \mathrm{O}_{3}$ ) зовнішній шар товщиною $h_{2}=95 \mu \mathrm{m} ;$ СДП-8 (сплав системи CoCrAlY з $24 \% \mathrm{Cr}$ i $11 \% \mathrm{Al}$ ) внутрішній шар товщиною $h_{1}=65 \mu \mathrm{m}$.

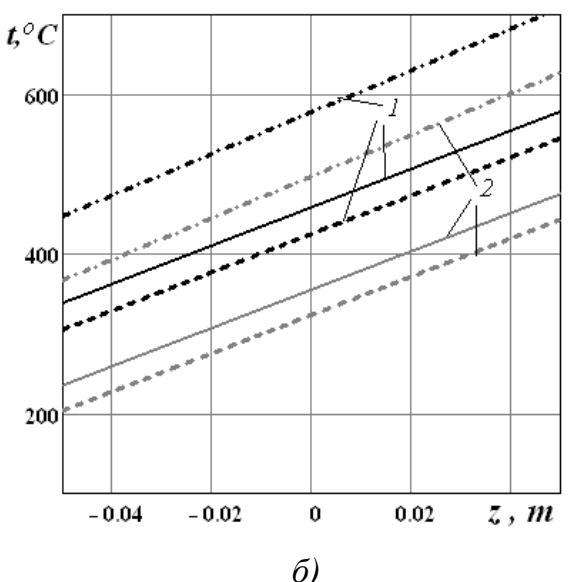

б)

Рис. 4. Розподіли температури вздовж радіуса ( $a$ ) (суцільна лінія $-z=0$; штрихова $-z=-h_{0} / 2$; штрихпунктирна $-z=h_{0} / 2$ ) і по товщині пластини (б) (штрихова $-\rho=0$; суцільна лінія $-\rho=0,25$; штрихпунктирна $-\rho=0,5): 1$ - для пластини без урахування покриття; 2 - 3 урахуванням покриття

Fig. 4. Temperature distributions along the radius (a) (solid line $-z=0$; dashed $-z=-h_{0} / 2$; dashed dash $\left.z=h_{0} / 2\right)$ and the thickness of the plate ( $\sigma$ ) (dashed $-\rho=0$; solid line $-\rho=0,25$; dashed dash $-\rho=0,5$ ): 1 - for the plate without taking into account the coating; 2 - taking into account the coverage

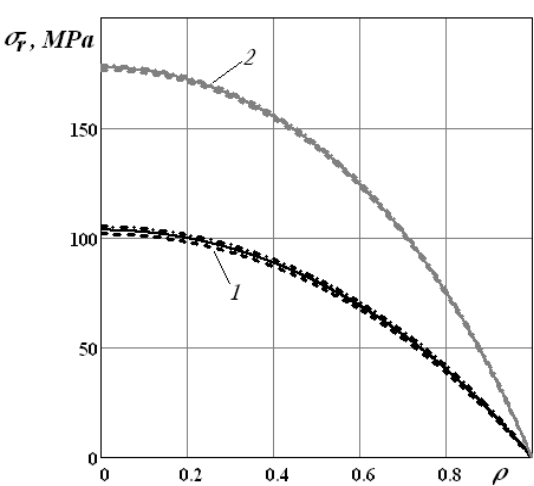

a)

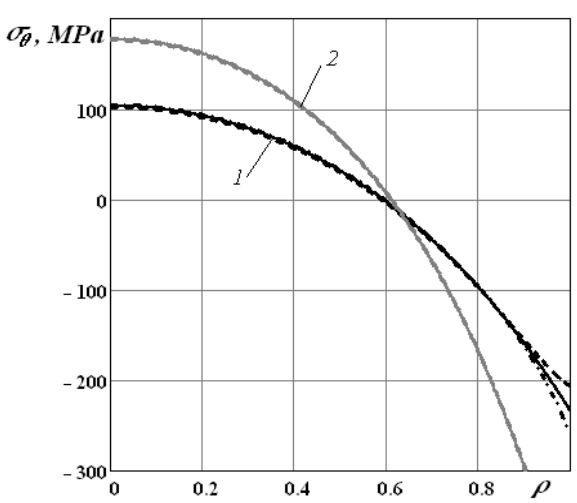

б)

Рис. 5. Розподіл напружень уздовж радіуса. Тут спостерігаємо протилежну картину. Врахування покриттів дає заниження значення напруження приблизно на $70 \mathrm{MPa} \mathrm{до} \mathrm{центру} \mathrm{пластини,} \mathrm{а} \sigma_{\theta}-\mathrm{i}$ до центру, і до краю

пластини. Розподіл напружень уздовж радіуса (суцільна лінія $-z=0$; штрихова $-z=-h_{0} / 2$; штрих-

пунктирна $\left.-z=h_{0} / 2\right)$ : 1 - для пластини без урахування покриття; 2 - $з$ урахуванням покриття

Fig. 5. The stress distribution along the radius is shown. Here, the opposite picture is seen. Consideration of coatings effect provides for reductionof the stress value by about $70 \mathrm{MPa}$ to the center of the plate, and - to the center and to the edge of the plate. Stress distribution along the radius (solid line $-z=0$; dashed $-z=-h_{0} / 2$; dashed dash $z=h_{0} / 2$ ): 1 - for the plate without coverage; 2 - taking into account the coverage 
Для розрахунків використані такі дані: $\lambda_{0}=24 \mathrm{~W} / \mathrm{m} \cdot \mathrm{C} ; \quad \lambda_{1}=10 \mathrm{~W} / \mathrm{m} \cdot \mathrm{C} ; \quad \lambda_{2}=2,5 \mathrm{~W} / \mathrm{m} \cdot \mathrm{C} ;$ $\alpha_{0}=150 \mathrm{~W} / \mathrm{m}^{2} \cdot \mathrm{C} ; \quad \alpha_{1}=80 \mathrm{~W} / \mathrm{m}^{2} \cdot \mathrm{C}$; $\alpha_{2}=15 \mathrm{~W} / \mathrm{m}^{2} \cdot \mathrm{C} ; \quad \alpha_{r}=100 \mathrm{~W} / \mathrm{m}^{2} \cdot \mathrm{C} ; \quad t_{m}^{c}=500^{\circ} \mathrm{C} ;$ $t_{n}^{c}=20^{\circ} \mathrm{C} ; t_{1}=800^{\circ} \mathrm{C}$.

Температуру пластини розраховували для двох випадків:

1) для пластини без покриття (див. рис. 4) 3 теплофізичними характеристиками $\alpha_{0}$ i $\lambda_{0}$;

2) 3 урахуванням покриття (див. рис. 5) $\left(\alpha_{0 m}\right.$, $\left.\alpha_{0 n}, \lambda_{0 m}, \lambda_{0 n}\right)$.

Висновки. Побудовано математичну модель для оболонки довільної форми 3 одностороннім та двостороннім багатошаровими тонкими покриттями, поверхні якої контактують із зовнішніми середовищами різних температур. Розв'язок тривимірної задачі теплопровідності оболонки з покриттям зведено до системи двох диференціальних рівнянь для інтегральних характеристик температури. Одержано в замкнутому вигляді точні розв'язки стаціонарних та нестаціонарних задач теплопровідності для круглої пластини та диска 3 двосторонніми тонкими багатошаровими покриттями.

3 представлених результатів розрахунків температури плити видно, що ігнорування покриттів завищує розрахункову температуру приблизно на $100{ }^{\circ} \mathrm{C} .3$ розподілу напружень ми спостерігаємо протилежну картину. Врахування покриттів дає зниження значення напружень приблизно на 70 МПа до центру пластини, а також до центру і до краю пластини.

\section{Бібліографічний список}

1. Аттетков А. В. Температурное поле твердого тела, содержащего цилиндрический канал с многослойным покрытием его поверхности, в условиях нестационарного теплообмена. Вестник МГТУ им. Н. Э. Баумана. Серия: Машиностроение. 2006. № 3. С. 37-50.

2. Берман Р. Теплопроводность твердых тел. Москва: Мир, 1979. 286 с.
3. Вейник А. И. Приближенный расчет процессов теплопроводности. Москва: Госэнергоиздат, 1959. $184 \mathrm{c}$.

4. Карслоу Г., Егер Д. Тепдопроводность твердых тел. Москва: Наука, 1964. 488 с.

5. Лыков А. В. Теория теплопроводности. Москва: Высш. шк., 1967. 600 с.

6. Максимук О., Щербина Я. Вплив захисного покриття на тепловий режим обмежених об'ємів. Вісник Львівського університету. Серія: Прикладна математика та інформатика. 2002. Вип. 4. С. 126-130.

7. Новацкий В. Обзор работ по динамическим проблемам термоупругости. Механика: сб. переводов. Москва, 1966. № 6(100). С. 101-142.

8. Підстригач Я. С., Ярема С. Я. Температурні напруження в оболонках. Київ: Вид-во АН УРСР, 1961. 212 c.

9. Подстригач Я. С., Коляно Ю. М. Неустановившиеся температурные поля и напряжения в тонких пластинках. Киев: Наук. думка, 1972. 308 с.

10. Подстригач Я. С., Чернуха Ю. А. Об уравнениях теплопроводности для тонкостенных элементов конструкций. Теория пластин и оболочек: тр. IX Всесоюз. конф. по теории оболочек и пластин. Ленинград, 1975. С. 82-85.

11. Семерак В. М., Косарчин В. I. Термонапружений стан в околі локальної ділянки фрикційного контакту. Вісник Львівського національного аграрного університету: агроінженерні дослідження. 2014. № 18. C. 271-275.

12. Шевчук В. А. Нестаціонарна одновимірна задача теплопровідності для циліндра 3 тонким багатошаровим покриттям. Математичні методи та фізико-механічні поля. 2011. № 2. С. 179-185.

13. Attetkov A. V., Belyakov N. S. The temperature field of an infinite solid containing a cylindrical channel with a thermally thin surface coating. High Temperature. 2006. 44, No. 1. P. 139-143.

14. Ionescu-Cazimir V. Theoreme de reciprocitate pentru problema dinamica a termo-elasticitii. An. Univ. Bucuresti. Ser. stiint. natur. 1963. Vol. 12, No. 39. P. 93-100.

15. Zorski H. On certain property of thermoelastic media. Bull. Acad, pol. sci. Ser. sci. techn. 1958. Vol. 6, No. 6. P. 331-339. 